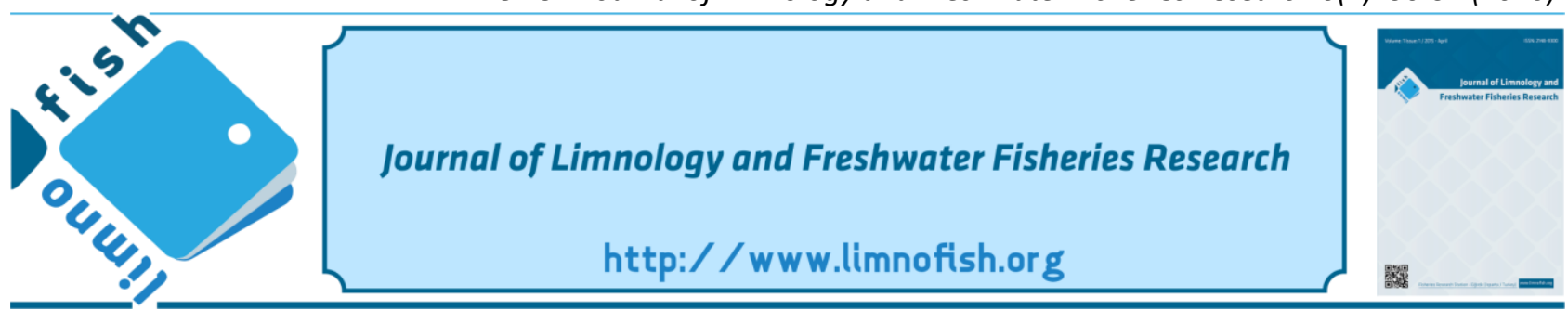

\title{
New Records for Tardigrada Species from the High Mountain Region in Turkey (Mount Verçenik, Rize)
}

\author{
Çağrı TEKATLI ${ }^{*}$ (i) Duygu BERDí ${ }^{2}$ (D) Şeyda FIKIRDEŞICI ERGEN² (i) Pınar GÜRBÜZER ${ }^{3}$ \\ Ahmet ALTINDAĞ ${ }^{2}$ iD
}

${ }^{1}$ Department of Biology, Institute of Natural and Applied Sciences, Ankara University, Ankara, Turkey.

${ }^{2}$ Faculty of Science, Department of Biology, Ankara University, Ankara, Turkey

${ }^{3}$ Department of Hydrobiology, Faculty of Fisheries, Sinop University, Sinop, Turkey

\section{A B STRACT}

Phylum Tardigrada, which has been quite a little studied both around the world and Turkey, belongs to members of a metazoan. In this study eight moss and lichen samples were collected and investigated from a variety of elevations of the Verçenik Mountain in Rize (Turkey). In total 62 specimens, 11 exivium and 10 eggs of tardigrades were found. Five species were identified, and they belong to genera: Acanthechiniscus, Pseudechiniscus, Macrobiotus, Paramacrobiotus and, Ramazzottius. Three of them are new records for Turkish fauna i.e. Acanthechiniscus victor (Ehrenberg, 1853), Pseudechiniscus ramazzottii ramazzottii Maucci, 1952 and Macrobiotus spectabilis Thulin, 1928. Including these three species, the tardigrade fauna of Turkey increased to 54. In this paper, we present the previous study a full list of the known high mountain and alpine tardigrade species with their localities. All specimens are deposited in the Aquatic Animals Research Laboratory at Ankara University.

Keywords: Acanthechiniscus victor, Alpine, fauna, Macrobiotus spectabilis, Pseudechiniscus ramazzottii ramazzottii
ARTICLE INFO

\section{RESEARCH ARTICLE}

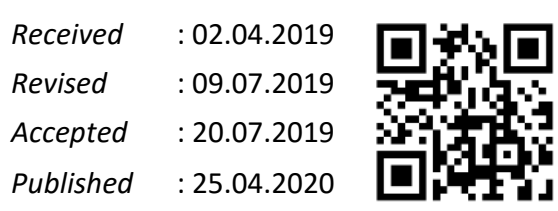

DOI:10.17216/LimnoFish.548238

\section{* CORRESPONDING AUTHOR}

cagritekatli@gmail.com

\section{Türkiye'nin Yüksek Dağ Bölgesinden Tardigrada Türleri için Yeni Kayıtlar (Verçenik Dağı, Rize)}

Öz: Dünyada ve Türkiye'de çok az çalışılmış olan Tardigrada filumu, metazoa üyelerine aittir. Bu çalışmada Rize'deki Verçenik Dağı'nın farklı yükseltilerinden elde edilen sekiz adet yosun ve 1 adet liken örneği toplanmış ve araştırılmıştır. Toplamda 62 birey, 11 exivium ve 10 tardigrat yumurtası bulunmuştur. Beş tür tespit edilmiş ve bunlar Acanthechiniscus, Pseudechiniscus, Macrobiotus, Paramacrobiotus ve Ramazzottius cinslerine aittir. Bunlardan üçü, Türkiye faunası için yeni kayıtlardır. Bunlar: Acanthechiniscus victor (Ehrenberg, 1853), Pseudechiniscus ramazzottii ramazzottii Maucci, 1952 ve Macrobiotus spectabilis Thulin, 1928. Bu üç türün de dahil edilmesiyle, Türkiye'nin tardigrat faunası 54'e yükselmiştir. Bu çalışmada daha önceden elde edilen yüksek dağ ve alpin türlerinin tam listesini sunulmuştur. Tüm örnekler Ankara Üniversitesi Sucul Canlıları Araştırma Laboratuvarında saklanmaktadır.

Anahtar kelimeler: Acanthechiniscus victor, Alpin, fauna, Macrobiotus spectabilis, Pseudechiniscus ramazzottii ramazzottii

How to Cite

Tekatlı Ç, Berdi D, Fikirdeşici Ergen Ş, Gürbüzer P, Altındağ A. 2020. New Records for Tardigrada Species from the High Mountain Region in Turkey (Mount Verçenik, Rize). LimnoFish. 6(1): 30-37. doi: 10.17216/LimnoFish.548238

\section{Introduction}

Tardigrades were first observed by German scientist Johann A. E. Goeze in 1773. Three years later Italian scientist Lazzaro Spallanzani (1776), gave them a name Tardigrada (meaning "slow stepper"). From the first discovery to date 1246 tardigrade species have been reported around the world (Degma and Guidetti 2007; Vicente and Bertolani 2013; Degma et al. 2018).
Very limited papers have been published on Turkish Tardigrada up to now (Kaczmarek et al. 2012). However, Maucci conducted quite intensive studies on Turkish tardigrade in 1973, 1975, 1978, 1979, 1980, 1981 and 1985. Later, only Morgan (1977), Binda (1988), Kaczmarek et al. (2012) and Ürkmez et al. (2018) reported a few more tardigrade species from this region and up to now only 51 species which are belonging to 18 genera have been recorded from Turkey. 
Lichens and mosses resistant to drought, which melt under the snow, grow under the snow, or in rock cracks, are encountered in Alpine zone. These plants which are durable to the drought may be exposed to the fundamental physical variances at short ranges because of the interaction between temperature and ground and also soil moisture which changes according to the effect of sun and wind (Atay et al. 2009). Tardigrades are one of the invertebrates adapting to these short-term physical changes and conformance to adverse environmental conditions.

There are very limited studies on the distribution and diversity of alpine tardigrades both in the world and in Turkey (Rodríguez-Roda 1951; Nelson 1975; Dastych 1980, 1985, 1987; Beasley 1988; Kathman and Cross 1991; Utsugi 1997; Collins and Bateman 2001; Nichols et al. 2001; Herrera-Vásquez and Vargas 2003; Guil et al. 2009; Kaczmarek et al. 2011). Up to now, only four species i.e. Hypsibius microps Thulin 1928, Echiniscus testudo (Doyère 1840), Echiniscus granulatus (Doyère 1840) and Richtersius coronifer (Richters, 1903), have been found in high mountain localities in Turkey (Maucci $1975,1978,1980)$. Some of the tardigrade species obtained from the alpine or subalpine zones are endemic only at certain altitudes, while others are cosmopolitan (Ramazzotti and Maucci 1983; Dastych 1988).

Our present study is the first high-altitude study to date on Turkish Tardigrada. Verçenik Mountain is located in the northern part of Turkey in Kaçkar Mountain Regions and originated from Alpide orogeny (Okay 2008). Up to now, zoogeographic and taxonomic information of tardigrades has been presented which is identified from alpine and subalpine zones in Turkey.

\section{Materials and Methods}

In August 2016, eight moss and lichen samples were collected on various altitudes of the Verçenik Mountain in Rize (Figure 1). But the tardigrades were found only in five of them (list of samples are presented in Table 1). All fresh samples were put into the small paper envelopes and allowed to dry slowly.

In the laboratory rehydrated samples were filtrated by the sieve of 25 and $400 \mu \mathrm{m}$, and the remaining residual was taken to a petri dish (Nelson 2002; Convey and McInnes 2005). Then tardigrades and their eggs were placed in a separate petri dish for identification on a stereomicroscope. All specimens were mounted on microscopic slides in Hoyer's medium, four adults and five eggs were prepared for Scanning Electron Microscopy (SEM) (JEOLJSM$6060 \mathrm{LV}$ ) analysis, following the protocols by Guidetti et al. (2000). The identification of specimens was carried out by analyzing morphological characters on the Phase-contrast microscope (Zeiss Axio ImagerM1) and SEM.

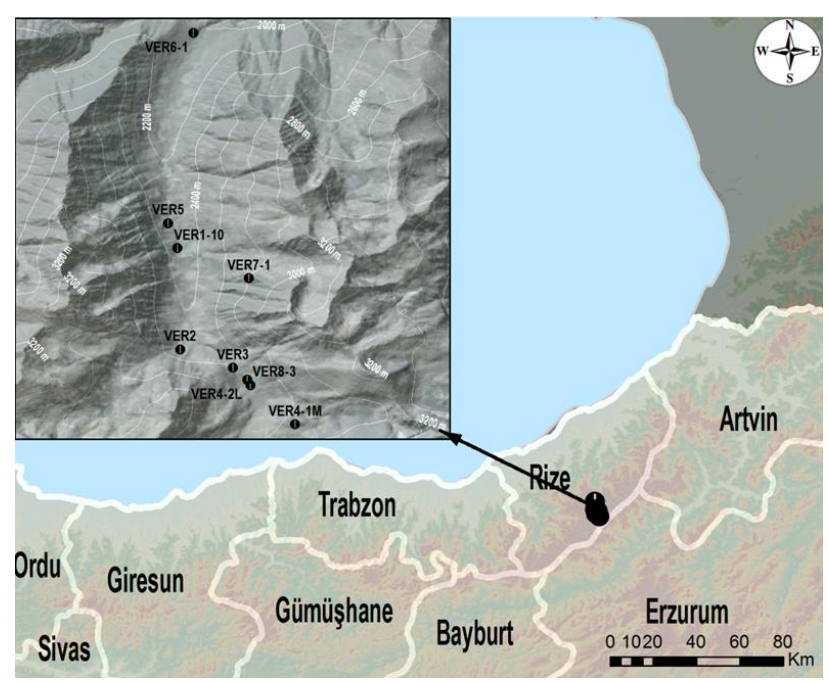

Figure 1. The geographic position of sampling sites.

Species were identified using a key to the world fauna of Tardigrada (Ramazzotti and Maucci 1983) and several original papers (Dastych 1988; Bertolani and Rebecchi 1993; Stec et al. 2018). All materials are deposited at the Aquatic Animals Research Laboratory at Ankara University.

Table 1. Distribution of the species found in the moss and lichen samples collected in Verçenik Mountain/Rize.

\begin{tabular}{|c|c|c|c|c|c|}
\hline Sample Code & Coordinates latitude, longitude & Date of collecting & $\begin{array}{c}\text { Above sea level } \\
\text { (a.s.l) }\end{array}$ & Habitat & $\begin{array}{c}\text { Species } \\
\text { composition }\end{array}$ \\
\hline VER1-10 & $\mathrm{N} 40^{\circ} 45^{\prime} 44^{\prime \prime}-\mathrm{E} 40^{\circ} 54^{\prime} 20^{\prime \prime}$ & $25 / 08 / 2016$ & $2308 \mathrm{~m}$ & Epilithic moss & $1,2,3$ \\
\hline VER2 & $\mathrm{N} 40^{\circ} 44^{\prime} 47^{\prime \prime}-\mathrm{E} 40^{\circ} 54^{\prime} 21^{\prime \prime}$ & $25 / 08 / 2016$ & $2247 \mathrm{~m}$ & Epilithic moss & - \\
\hline VER3 & N404' $36^{\prime \prime}$ - E405'ㄴ' & $25 / 08 / 2016$ & $2131 \mathrm{~m}$ & Epilithic moss & 5 \\
\hline VER4-1M & N404'05" - E4055'26" & $26 / 08 / 2016$ & $2606 \mathrm{~m}$ & Epilithic moss & 4 \\
\hline VER4-2L & N4044'30" - E4054'59" & $26 / 08 / 2016$ & $2606 \mathrm{~m}$ & Lichen & 1 \\
\hline VER5 & N4045'58" - E4054'14" & $26 / 08 / 2016$ & $2145 \mathrm{~m}$ & Epilithic moss & - \\
\hline VER6-1 & 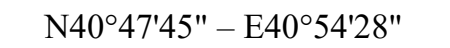 & $26 / 08 / 2016$ & $2214 \mathrm{~m}$ & Epilithic moss & 1,3 \\
\hline VER7-1 & $\mathrm{N} 40^{\circ} 45^{\prime} 27^{\prime \prime}-\mathrm{E} 40^{\circ} 55^{\prime} 00^{\prime \prime}$ & $26 / 08 / 2016$ & $2610 \mathrm{~m}$ & Epilithic moss & - \\
\hline VER8-3 & 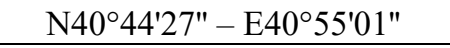 & $26 / 08 / 2016$ & $2611 \mathrm{~m}$ & Epilithic moss & 1,5 \\
\hline
\end{tabular}




\section{Results}

A total of 62 specimens, 10 eggs, and 11 exivium were isolated and 5 species were identified. Three of them are new records for the Turkish Tardigrade fauna. A list of the identified Turkish high mountain and alpine tardigrade, with their localities and zoogeographical and taxonomic comments, are in Table 2.

Table 2. List of all obtained tardigrade species from Turkish high mountains and alpine regions, with their localities, and zoogeographical and taxonomic comments.

\begin{tabular}{|c|c|c|c|}
\hline Taxa & asl** & Localities & Remarks \\
\hline $\begin{array}{l}\text { Cornechiniscus cornutus } \\
\text { (Richters, 1907) }\end{array}$ & $2400 \mathrm{~m}$ & $\begin{array}{l}\text { Europe; Turkey, Bulgaria, Romania, Italy, } \\
\text { Germany, Greece, Switzerland, Poland, Austria, } \\
\text { Ireland, France, Russia, Africa; Algeria (McInnes } \\
\text { et al. 2017), Libya, Asia; Iran, Afghanistan, } \\
\text { India, Mongolia, Pakistan, China, N. America; } \\
\text { Canada (6). }\end{array}$ & $\begin{array}{l}\text { It was found in Erzurum/Pasinler } \\
(3,4) \text {. But according to Dastych } \\
(1988), \text { it classified as submontane } \\
\text { and distributed in Holarctic }(6) \text {. }\end{array}$ \\
\hline $\begin{array}{l}\text { Echiniscus granulatus } \\
\text { (Doyère, } 1840 \text { ) }\end{array}$ & $2400 \mathrm{~m}$ & $\begin{array}{l}\text { Europe; Italy, Turkey, France Greece Norway, } \\
\text { Croatia, Austria, England, Ireland, Spain, Poland, } \\
\text { Hungary, Germany, Portugal, Bulgaria, Africa; } \\
\text { Morocco, Algeria, Russia, Georgia, Asia; Iran, } \\
\text { Pakistan, Mongolia, Indonesia, } \\
\text { N. America (6). }\end{array}$ & $\begin{array}{l}\text { It was observed in Erzurum/Pasinler } \\
\text { from Turkey (3). It is submontane } \\
\text { and distributed in Holarctic (Dastych } \\
\text { 1988). }\end{array}$ \\
\hline $\begin{array}{l}\text { Echiniscus merokensis suecicus } \\
\text { Thulin, } 1911\end{array}$ & $2200 \mathrm{~m}$ & $\begin{array}{l}\text { Europe; Turkey, Italy, Norway, } \\
\text { Scotland, England; } \begin{array}{r}\text { Sweden, } \\
\text { Iceland, Alps, }\end{array} \\
\text { Czechoslovakia, France, Yugoslavia, } \\
\begin{array}{l}\text { Switzerland, Africa; Angola, N. America; } \\
\text { Greenland (6). }\end{array}\end{array}$ & $\begin{array}{l}\text { It was reported in Bursa/Uludağ } \\
\text { Mountain at } 2200 \mathrm{~m}(2,3) \text { but it was } \\
\text { found between } 0 \text { and } 400 \mathrm{~m} \text { in the } \\
\text { Faroe Islands by Trygvadóttir and } \\
\text { Kristensen (2013). }\end{array}$ \\
\hline $\begin{array}{l}\text { Echiniscus testudo } \\
\text { (Doyère, 1840) }\end{array}$ & $\begin{array}{c}2000- \\
2400 \mathrm{~m}\end{array}$ & $\begin{array}{l}\text { It is a cosmopolitan species and Holarctic. Its } \\
\text { distribution is most of the Palearctic } \\
\text { biogeographic region (6, Jørgensen et al. 2007, } \\
\text { McInnes et al. 2017). }\end{array}$ & $\begin{array}{l}\text { It was only observed in Erzurum and } \\
\text { Ağr1 from Turkey }(2,3) \text {. In contrast, } \\
\text { it was found between } 0 \text { and } 200 \mathrm{~m} \text { in } \\
\text { the Faroe Islands by Trygvadóttir } \\
\text { and Kristensen. (2013). }\end{array}$ \\
\hline $\begin{array}{l}\text { Ramazzottius oberl } \\
\text { (Doyére, 1840) }\end{array}$ & $2000 \mathrm{~m}$ & $\begin{array}{l}\text { It is a cosmopolitan, known from numerous } \\
\text { locations in Europe from Greenland, the Arctic } \\
\text { and Antarctic, North and South America, Africa, } \\
\text { Afghanistan and New Zealand (Ramazzotti and } \\
\text { Maucci 1983, McInnes et al. 2017). }\end{array}$ & $\begin{array}{l}\text { It was observed in many cities in } \\
\text { Turkey }(1,2,3,4,5) \text { and reported at an } \\
\text { altitude of } 4.300 \mathrm{~m} \text { in Mount } \\
\text { Blancgroup/Europe (Ramazzotti and } \\
\text { Maucci 1983). }\end{array}$ \\
\hline $\begin{array}{l}\text { Acanthechiniscus } \\
\text { (Ehrenberg, 1853) }\end{array}$ & $\begin{array}{l}2606 \mathrm{~m} \\
(7)\end{array}$ & $\begin{array}{l}\text { Europe; Turkey (7), Italy, Romania, Switzerland, } \\
\text { Poland, Alps, Norway, Iceland), Russia. North } \\
\text { America, Canada; Axel Heiburg Island, } \\
\text { Greenland (6). }\end{array}$ & $\begin{array}{l}\text { In this study, it was found from rock } \\
\text { mosses and lichen in Rize/Verçenik } \\
\text { Mountain. } \\
\text { According to Ramazzotti (1956), it is } \\
\text { classified as an alpine. }\end{array}$ \\
\hline $\begin{array}{l}\text { Pseudechiniscus facettalis } \\
\text { Petersen, } 1951\end{array}$ & $\begin{array}{c}1200- \\
1600 \mathrm{~m}\end{array}$ & $\begin{array}{l}\text { Europe; Turkey, Italy, Austria, Greece, Alps, } \\
\text { Portugal, Spain, Africa; Kenya (McInnes et al. } \\
\text { 2017), New Zealand; South Island, North } \\
\text { America; Canada; Axel Heiburg Island, } \\
\text { Greenland, South America; Brazil, Venezuela, } \\
\text { Tierra del Fuego (6). }\end{array}$ & $\begin{array}{l}\text { Although these species have been } \\
\text { reported at low altitude, it is still } \\
\text { classified as alpine species by } \\
\text { Ramazzotti (1956). It was found } \\
\text { Bozdağ/Izmir in Turkey }(1,2,3) \text {. }\end{array}$ \\
\hline $\begin{array}{l}\text { Pseudechiniscus ramazzottii } \\
\text { ramazzottii Maucci, } 1952 *\end{array}$ & $\begin{array}{l}2308 \mathrm{~m} \\
(7)\end{array}$ & $\begin{array}{l}\text { Europe; Turkey, Italy, Hungary, Alps, Russia, } \\
\text { North and South America }(6,7) \text {. }\end{array}$ & $\begin{array}{l}\text { This species is a new record for } \\
\text { Turkey. It was collected in moss } \\
\text { samples from rock (7). }\end{array}$ \\
\hline $\begin{array}{l}\text { Hypsibius microps Thulin, } \\
1928\end{array}$ & $1.800 \mathrm{~m}$ & $\begin{array}{l}\text { Europe; Turkey, Italy, Istria, Turkey, Sweden, } \\
\text { Finland, Norway, Greece, Poland, Hungary, } \\
\text { Austria, Czech Republic, Portugal, Spain, } \\
\text { Bulgaria, Russia, Africa; Algeria, Asia; India, } \\
\text { Mongolia, Korea, N. America; Greenland; Disko } \\
\text { Island, S. America; Brazil, Argentina (6). }\end{array}$ & $\begin{array}{l}\text { Known only from two localities in } \\
\text { Turkey }(2,3) \text {. Cosmopolitan }(6) \text {, } \\
\text { however records of this species need } \\
\text { to be verified (Kaczmarek and } \\
\text { Michalczyk 2009). }\end{array}$ \\
\hline $\begin{array}{l}\text { Isohypsibius duranteae } \\
\text { (Maucci, 1978) }\end{array}$ & $\begin{array}{l}2200- \\
2400 \mathrm{~m}\end{array}$ & It is endemic for Turkey $(3,6)$. & $\begin{array}{l}\text { It was only collected in } \\
\text { Erzurum/Pasinler, Ağrı/ Tahir and } \\
\text { originally described from Turkey (3). }\end{array}$ \\
\hline $\begin{array}{l}\text { Isohypsibius macrodactylus } \\
\text { (Maucci, 1978) }\end{array}$ & $2400 \mathrm{~m}$ & $\begin{array}{l}\text { Europe; Turkey, Cyprus, Italy, Russia, Africa; } \\
\text { Algeria (6; Tekatlı and Altındağ 2017). }\end{array}$ & $\begin{array}{l}\text { It was reported in Ağrı and originally } \\
\text { described from Turkey (3). On the } \\
\text { other hand, it occurred at lowland } \\
\text { altitudes ( } 13 \mathrm{~m} \text { asl) in Cyprus } \\
\text { (Tekatlı and Altındağ 2017). }\end{array}$ \\
\hline $\begin{array}{l}\text { Mesobiotus harmsworthi } \\
\text { (Murray, 1907) }\end{array}$ & $1450 \mathrm{~m}$ & $\begin{array}{l}\text { Cosmopolitan species, known from many } \\
\text { localities throughout the world (6), but the } \\
\text { species' geographic range is unknown } \\
\text { (Kaczmarek et al. 2012). }\end{array}$ & $\begin{array}{l}\text { It was observed in Ağrı, Antalya, } \\
\text { Bolu, Burdur, Bursa, Izmir and } \\
\text { Kastamonu from Turkey }(1,2,3) \text {. }\end{array}$ \\
\hline
\end{tabular}


Table 2. Continued

\begin{tabular}{|c|c|c|c|}
\hline Taxa & asl** & Localities & Remarks \\
\hline $\begin{array}{l}\text { Macrobiotus pallarii } \\
\text { Maucci, } 1954\end{array}$ & $2000 \mathrm{~m}$ & $\begin{array}{l}\text { Europe; Turkey, Italy, Poland, Yugoslavia, } \\
\text { Greece, Norway, Turkey, Hungary, Russia, Asia; } \\
\text { North Korea, N. America (6). }\end{array}$ & $\begin{array}{l}\text { It was reported in Bolu, Kastamonu, } \\
\text { and Tunceli from Turkey }(1,2,3) \text {. }\end{array}$ \\
\hline $\begin{array}{l}\text { Macrobiotus persimilis } \text { Binda } \\
\text { and Pilato, } 1972\end{array}$ & $2000 \mathrm{~m}$ & $\begin{array}{l}\text { Europe; Turkey, Italy, Greece, Spain, Portugal, } \\
\text { Africa; Tunisia, Libya, Australia; Sydney, N. } \\
\text { America; Greenland (6). }\end{array}$ & $\begin{array}{l}\text { It was found in Balıkesir, Bolu, } \\
\text { Diyarbakır, Erzincan, Sakarya, Uşak } \\
\text { and Van from Turkey }(2,4) \text {. }\end{array}$ \\
\hline Macrobiotus spectabilis & $2308 \mathrm{~m}$ & Europe; Turkey, Poland, Norway, Sweden, Italy, & The present study, it was collected \\
\hline Thuli & (7) & $\begin{array}{l}\text { France, Russia, North America, South America } \\
(6,7) \text {. }\end{array}$ & $\begin{array}{l}\text { from rock moss in Rize/Verçenik } \\
\text { Mountain from Turkey. }\end{array}$ \\
\hline $\begin{array}{l}\text { Tenuibiotus hystricogenitus } \\
\text { (Maucci, 1978) }\end{array}$ & $\begin{array}{c}1350- \\
2400 \mathrm{~m}\end{array}$ & Europe; Turkey, Germany, Greece (6). & $\begin{array}{l}\text { It was found in Erzurum and Çorum } \\
\text { from Turkey (3). }\end{array}$ \\
\hline $\begin{array}{l}\text { Richtersius coronifer } \\
\text { (Richters, 1903) }\end{array}$ & $1800 \mathrm{~m}$ & $\begin{array}{l}\text { Europe; Turkey, Norway, Sweden, Italy Greece, } \\
\text { Scotland, Spain, Poland, Austria, France, } \\
\text { Switzerland, Bulgaria, Hungary, Romania, } \\
\text { Germany, Arctic, Africa; Tunisia, Algeria, } \\
\text { Congo, Asia; Nepal, Mongolia, North America } \\
\text { and South America (6, McInnes et al. 2017). }\end{array}$ & $\begin{array}{l}\text { It was found in Ağrı, Çorum, Izmir, } \\
\text { Van from Turkey }(2,3,4) . R \text {. } \\
\text { coronifer is considered as an alpine } \\
\text { species by Ramazzotti (1956). }\end{array}$ \\
\hline
\end{tabular}

Source codes: 1- Maucci (1973), 2- Maucci (1975), 3- Maucci (1978), 4- Maucci (1979), 5- Maucci (1980), 6- McInnes (1994), 7- present study. Asterisks $\left(^{*}\right)$ are symbolized as a new record and (**) obtained from Turkish territory altitude. The list of species ordered according to Degma et al. (2018).

\section{Taxonomic accounts}

New records for Turkey were marked by an asterisk $(*)$.

Phylum: Tardigrada Spallanzani, 1777

Class: $\quad$ Heterotardigrada Marcus, 1927

Order: Echiniscoidea Marcus, 1927

Family: Echiniscidae Thulin, 1928

Genus: Acanthechiniscus Vecchi, Cesari, Bertolani, Jönsson, Rebecchi and Guidetti, 2016

\section{Acanthechiniscus victor (Ehrenberg 1853)*}

Material examined: 25 specimens and 6 exuviae collected from two rock mosses and lichen.

Remarks: Species new for Turkey and most abundant in studied samples (Figure 2). It is considered an alpine species by Ramazzotti (1956). The specimens obtained correspond perfectly to the characterization of this species by Ramazzotti and Maucci (1983) and Dastych (1988). It has been recorded in many countries (Italy, Romania, Switzerland, Poland, Alps, Spitsbergen, Iceland, USSR, USA, Canada, Greenland) (McInnes 1994).

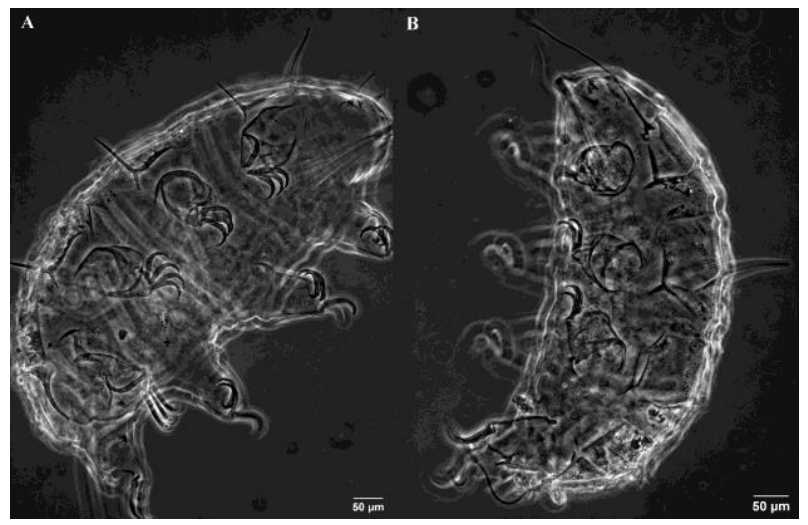

Figure 2. Acanthechiniscus victor. A) View of the ventral side B) Dorsal view.
Genus: Pseudechiniscus Thulin, 1911

\section{Pseudechiniscus ramazzottii ramazzottii Maucci, 1952*}

Material examined: 12 specimens and 2 exivium collected from two rock moss.

Remarks: Up to now it has been recorded sixth times (Italy, Hungary, Alps, Russia, North and South America), Ramazzotti (1956), Ramazzotti and Maucci (1983) and Iharos (1985). In this study, it was collected from moss samples at $2308 \mathrm{~m}$ (Figure 3).

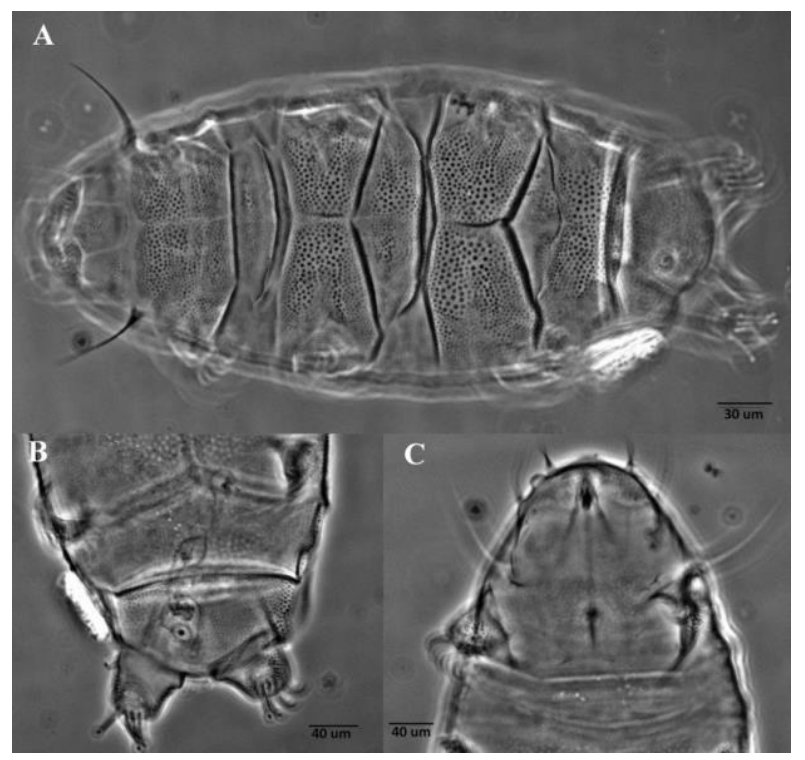

Figure 3. Pseudechiniscus ramazzottii ramazzottii A) Dorsal view B) Caudal margin of the pseudosegmental plate C) View of cephalic zone.

Class: Eutardigrada Richters, 1926

Order: Parachela Schuster, Nelson, Grigarick and Christenberry, 1980

Family: Macrobiotidae Thulin, 1928

Genus: Macrobiotus C.A.S. Schultze, 1834 


\section{Macrobiotus spectabilis Thulin, 1928*}

Material examined: 6 specimens and 3 eggs collected from two rock moss.

Remarks: It is a new record for Turkey. It was observed from rock mosses at an altitude of 2308 meters in Rize/Verçenik Mountain (Figure 4). According to Dastych (1988), it is classified as a mountain (mesoalpine) species. It is known from few localities from Siberia, Poland, Italy, France, Finland, Russia, USA, Argentina, China and Norway (Ramazzotti and Maucci 1983; McInnes 1994; Zhang and Sun 2014). The found specimens correspond perfectly to the characterization of this species presented by Dastych (1973) and Maucci and Pilato (1974).

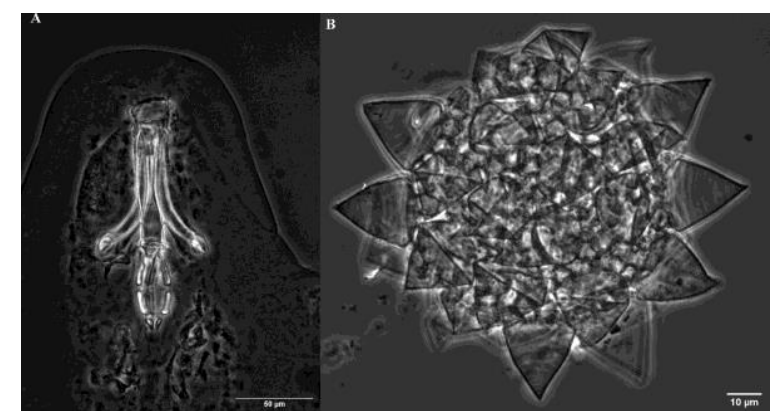

Figure 4. Macrobiotus spectabilis A) Buccal apparatus B) Egg.

Genus: Paramacrobiotus Guidetti, Schill, Bertolani, Dandekar and Wolf, 2009

Subgenus Paramacrobiotus Guidetti, Schill, Bertolani, Dandekar and Wolf, 2009

\section{Paramacrobiotus cf. richtersi (Murray, 1911)}

Material examined: 5 specimens and 3 eggs collected from rock moss.

Remarks: It is one of the species of more common tardigrades and widespread everywhere, and present in different habitats, including terrestrial moss (Ramazzotti and Maucci 1983). In the study of Dastych (1988), on polish tardigrades, this species found in an area up to 2000 meters high. In this study, it was obtained from rock mosses at an altitude of $2131 \mathrm{~m}$ (Figure 5). In Turkey, it was collected between 250-1140 m altitude in Ankara, Antalya, Burdur, Çanakkale, İzmir and Van (Maucci 1973, 1975, 1980; Kaczmarek et al. 2012). But this genus has been revised by some researchers Kaczmarek et al. 2017; Marley et al. 2018).

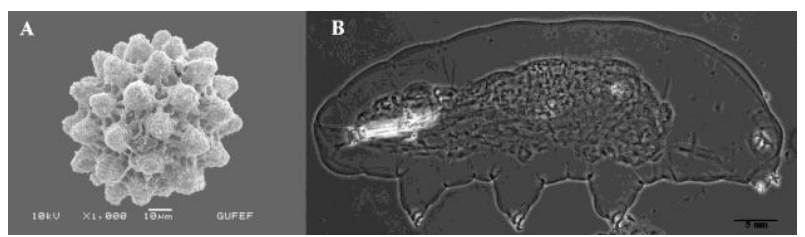

Figure 5. Paramacrobiotus cf. richtersi A) Egg B) View of the ventro-dorsal side.
Family: Ramazzottiidae Sands, McInnes, Marley, Goodall-Copestake, Convey, and Linse, 2008

Genus: Ramazzottius Binda and Pilato, 1986

\section{Ramazzottius oberhaeuseri (Doyère 1840)}

Material examined: 11 specimens and 3 eggs collected from two rock moss samples.

Remarks: According to Ramazotti (1956), this species is not alpine but can be encountered high altitude in Poland (Dastych 1988). It is an extremely wide-spread and very common species (Ramazzotti and Maucci 1983). It was found in Afyonkarahisar, Ağrı, Ankara, Antalya, Bolu, Çorum, Erzincan, Erzurum, Hakkari, Gaziantep, Kastamonu, Kırkareli, Uşak, Konya, Tunceli, Van between 250-2000 m from Turkey (Maucci 1973, 1975, 1978; Morgan 1977; Kaczmarek et al. 2012). All records of Ramazzottius oberhaeuseri prior to its redescription (Stec et al. 2018) should be verified (Figure 6).

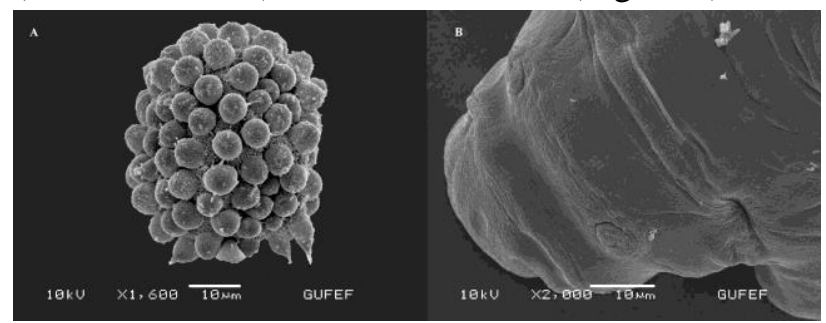

Figure 6. Ramazzottius oberhaeuseri A) Egg B) Eliptical organ.

\section{Discussion}

Alpine, subalpine, boreo-alpine, and nival regions are one of the few studied regions, as access to these regions is both difficult and land conditions are appropriate only during a certain period of summer. So far, the number of Tardigrada obtained in studies on these regions in the world is quite limited.

The alpine regions are located above the last tree line (Pechlaner 1971). Some researchers have splitthe tardigrade species into groups according to altitudinal ranges and localities (Ramazzotti and Maucci 1983; Dastych 1987). Ramazzotti and Maucci (1983), defined tardigrade species obtained from $500 \mathrm{~m}$ and above areas as alpine species, while Dastych (1988), defined the lower limit as $1000 \mathrm{~m}$. In addition, studies are showing that the alpine region starts at $400 \mathrm{~m}$ and above (Trygvadottir and Kristensen 2013). The alpine zone varies according to the region in Turkey. Subalpine regions begin at about $1800 \mathrm{~m}$. After approximately $2000 \mathrm{~m}$, it continues as typical alpine regions (Atay et al. 2009). The alpine zone for Verçenik Mountain starts at $2000 \mathrm{~m}$ (Gürbüzer 2018). Therefore, our samples can be classified as alpine species. Previously obtained alpine species 
from Turkey were compared with this study (Table 2).

In the studies conducted so far, not only the distribution, abundance and diversity of the elevation according to species, but also the species obtained from different regions in the same alpine zone have been studied (Collins and Bateman 2001; Trygvadottir and Kristensen 2013). According to Dastych (1980); increasing the number of individuals together with the height decreased; In his research in 1987, he stated that species diversity increased as the height increased. This result was supported by Rodríguez-Roda (1951). Additionally, Guil et al. (2009) cited that the abundance of a tardigrade is the highest at 1000-2000 $\mathrm{m}$ asl.; the lowest is $0-500 \mathrm{~m}$ asl. But other researchers have found that the abundance is not more than $0-500 \mathrm{~m}$. asl (Utsugi 1997; Collins and Bateman 2001). Furthermore, Nichols (1999) stated that there is no relationship between height and tardigrade distribution in the study of the distribution of tardigrade on Dugger Mountain in Alabama. In addition, Kathman and Cross (1991) found in their research that there is no effect of height on tardigrades in the Mountains of Vancouver in Canada. Kaczmarek et al. (2011) cited that, even not linear, increasing of height revealed the abundance of a tardigrade. It is possible to reach tardigrade which is not very common in algae samples obtained at 2000- and 4000-meters altitude (Ramazzotti and Maucci 1983).

It is known that temperature, humidity, food availability, competition, predation, and parasitism are effective on tardigrade populations (Dastych 1982; Ramazzotti and Maucci 1983; Collins and Bateman 2001). Although there are limited studies on the effect of biotic and abiotic factors on the animal, some researchers have tried to understand whether the altitude has a role in this living organism. There have been contradictory studies on this subject, but some researchers have found a correlation between height and diversity (Kaczmarek et al. 2011).

Most of the Tardigrade species obtained in Turkey at 2000 meters and above are observed to be tychoalpine species (an organism that is found at every altitude) compared to other areas. There is no study available on these creatures obtained associated with altitude. Until now, the relationship between the species obtained up to 2000 meters and above and altitude has not been determined when compared with other studies. The reason for this difference is thought to be due to the environmental conditions and microhabitat where the samples are exposed to, rather than the effect of the altitude on the habitat where the samples are taken.

Many studies on the Phylum Tardigrada have focused on limnoterrestrial tardigrades, which are easy to access and have a lot of diversity. Since transportation and weather conditions are difficult in Alpine regions, very few studies have been done so far. The data obtained is not enough to illuminate the distribution and diversity of the tardigrades in these regions. In the future, studies in high-altitude regions will give us more information about the distribution and characteristics of these animals.

\section{Acknowledgments}

We thank the Institute of Biotechnology at Ankara University for providing logistical support during the laboratory work. We also thank Ankara University because the specimens were collected during the field studies of the project that grant number 15B0430004.

\section{References}

Atay S, Güleryüz G, Orhun C, Seçmen Ö, Vural C. 2009. Dağlarımızdaki zenginlik Türkiye'nin 120 alpin bitkisi. İstanbul: Dönence Basım Yayın Hizmetleri $98 \mathrm{~s}$.

Bertolani R. Rebecchi L. 1993. A revision of the Macrobiotus hufelandi group (Tardigrada, Macrobiotidae), with some observations on the taxonomic characters of eutardigrades. Zool Scr. 22(2):127-152. doi: 10.1111/j.1463-6409.1993.tb00347.x

Beasley, C.W. 1988. Altitudinal distribution of Tardigrada of New Mexico with the description of a new species. Am Midl Nat. 120 (2): 436-440 doi: $10.2307 / 2426016$

Binda MG. 1988. Redescrizione di Macrobiotus echinogenitus Richters, 1904 e sul valore di buona specie di Macrobiotus crenulatus Richters, $1904 \quad$ (Eutardigrada). Animalia. 15(1/3):201-210.

Collins M, Bateman L. 2001. The ecological distribution of tardigrades in Newfoundland. Zool Anz. 240(3-4):291-297. doi: 10.1078/0044-5231-00036

Convey P, Mc Innes SJ. 2005. Exceptional tardigradedominated ecosystems in Ellsworth Land, Antarctica. Ecology. 86(2):519-527. doi: 10.1890/04-0684

Dastych H. 1973. Redescription of Macrobious spectabilis, Thulin, 1928. (Tardigrada). Bull Pol Acad Sci-Te. 21(12):823-825.

Dastych H. 1980. Niesporczaki (Tardigrada) Tatrzanskiego Parku Narodowego. Warszawa: Monografie Fauny Polski 232 p.

Dastych, H. 1982. An annotated list of Alaskan Tardigrada. Pol Polar Res. 3(1-2): 95-102.

Dastych H. 1985. West Spitzbergen Tardigrada. Acta Zool Cracov. 28(3):169-214.

Dastych H. 1987. Altitudinal distribution of Tardigrada in Poland. In: Bertolani R, editor. Biology of Tardigrades: Selected Symposia and Monographs. Modena, Italia: Unione Zoologia. p. 169-214. 
Dastych H. 1988. The Tardigrada of Poland (Monografie Fauny Polski). Polish: Państwowe Wydawn 255 p.

Degma P, Guidetti R. 2007. Notes to the current checklist of Tardigrada. Zootaxa. 1579(1):41-53. doi: 10.11646/zootaxa.1579.1.2

Degma P, Bertolani R, Guidetti R. 2018. Actual checklist of Tardigrada species (2009-2019, Ver: 35: 31-072019); [cited 08 Dec 2019]. Available from https://iris.unimore.it/retrieve/handle/11380/117 8608/226739/Actual\%20checklist\%20of\%20Tardigr ada\%2035th\%20Edition.pdf

Goeze JAE. 1773. Über den kleinen Wasserbär. In: Bonnet $\mathrm{HK}$, editor. Abhandlungen aus der Insectologie, Ubers. Abh. Insektologie. Halle, Germany: Usw 2. Beobachtg. p. 367-375.

Guidetti R, Rebecchi L, Bertolani R. 2000. Cuticule structure and systematics of the Macrobiotidae (Tardigrada, Eutardigrada). Acta Zool.-Stockholm 81(1):27-36. doi: 10.1046/j.1463-6395.2000.00034.x

Guil N, Hortal J, Sanchez-Moreno S, Machordom A. 2009. Effects of macro and micro-environmental factors on the species richness of terrestrial tardigrade assemblages in an Iberian mountain environment. Landscape Ecol. 24(3):375-390. doi: 10.1007/s10980-008-9312-x

Gürbüzer P. 2018. Investigation of the zooplankton fauna and phylogenetic analysis of Daphnia in alpine lakes of Kackarlar and Aladaglar mountain regions [PhD Thesis]. Ankara University. 120 p. [in Turkish]

Herrera-Vásquez J, Vargas M. 2003. Tardigrades (Tardigrada) from the western part of the Central Valley, Costa Rica with some ecological annotations. Brenesia. 59(60):69-76.

Iharos G. 1985. Revidierter katalog der Tardigraden Ungarns. Miscellanea Zoologica Hungarica. 3:19-30.

Jørgensen A, Møbjerg N, Kristensen RM. 2007. A molecular study of the tardigrade Echiniscus testudo (Echiniscidae) reveals low DNA sequence diversity over a large geographical area. J Limnol. 66(1):77-83. doi: 10.4081/jlimnol.2007.s1.77

Kaczmarek Ł, Michalczyk Ł. 2009. Redescription of Hypsibius microps Thulin, 1928 and H. pallidus Thulin, 1911 (Eutardigrada: Hypsibiidae) based on the type material from the Thulin collection. Zootaxa. 2275:60-68. doi: 10.5281/zenodo.191059

Kaczmarek Ł, GoŁdyn B, WeŁnicz W, Michalczyk Ł. 2011. Ecological factors determining Tardigrada distribution in Costa Rica. J Zool Syst Evol Res. 49(1):78-83. doi: 10.1111/j.1439-0469.2010.00603.x

Kaczmarek Ł, Jakubowska N, Michalczyk Ł. 2012. Current knowledge on Turkish tardigrades with a description of Milnesium beasleyi sp. nov. (Eutardigrada: Apochela: Milnesiidae, the granulatum group). Zootaxa. 3589(1):49-64. doi: 10.11646/zootaxa.3589.1.3

Kaczmarek Ł, Gawlak M, Bartels PJ, Nelson DR, Roszkowska M. 2017. Revision of the genus Paramacrobiotus Guidetti et al., 2009 with the description of a new species, re-descriptions and a key. Ann Zool. 67(4):627-656.

doi: 10.3161/00034541anz2017.67.4.001

Kathman RD, Cross SF. 1991. Ecological distribution of moss-dwelling tardigrades on Vancouver Island, British Columbia, Canada. Can J Zool. 69(1):122-129. doi: 10.1139/z91-018

Marley NJ, Gawlak M, Bartels PJ, Nelson DR, Roszkowska M, Degma P. 2018. A clarification for the subgenera of Paramacrobiotus Guidetti, Schill, Bertolani, Dandekar and Wolf, 2009, with respect to the International Code of Zoological Nomenclature. Zootaxa. 4407(1):130-134.

doi: 10.11646/zootaxa.4407.1.9

Maucci W. 1973. Tardigradi muscicoli della Turchia. Memorie del Museo Civico di Storia. Naturale di Verona. 20:169-221.

Maucci W. 1975. Tardigradi muscicoli della Turchia (secondo contributo). Bollettino Museo civico Storia naturale, Verona. 1:255-275.

Maucci W. 1978. Tardigradi muscicoli della Turchia (terzo contributo). Bollettino Museo civico Storia naturale, Verona. 5:111-140.

Maucci W. 1979. I Pseudechiniscus del gruppo cornutus, con descrizione di una nuova specie (Tardigrada, Echiniscidae). Zeszty Naukowe Uniwersytetu Jagiellońskiego, Prace Zoologiczne Krakow. 25:107-124.

Maucci W. 1980. Analisi preliminare di alcuni dati statistici sulla ecologia dei tardigradi muscicoli. Bollettino del Museo Civico di Stori Naturale, Verona. 7:1-47.

Maucci W. 1981. Analisi di alcune biocenosi relative a Tardigradi muscicoli. Bollettino del Museo Civico di Storia Naturale, Verona. 8:67-83.

Maucci W. 1985. Materiali per una revisione del genere Echiniscus Schultze, 1840. I. Il complesso blumi (Heterotardigrada, Echiniscidae). Bollettino del Museo Civico di Storia Naturale di Verona. 12:109-139.

Maucci W, Pilato G. 1974. Macrobiotus spectabilis Thulin, 1928 e Macrobiotus grandis Richters, 1911: due buone specie di Eutardigradi. Animalia. 11(3):245-256.

McInnes SJ. 1994. Zoogeographic distribution of terrestrial/freshwater tardigrades from current literature. J Nat Hist. 28(2):257-352. doi: 10.1080/00222939400770131

McInnes SJ, Michalczyk Ł, Kaczmarek Ł. 2017. Annotated zoogeography of non-marine Tardigrada: part IV: Africa. Zootaxa. 4284(1):1-74. doi: 10.11646/zootaxa.4284.1.1

Morgan CI. 1977. An Annotated Catalogue of Tardigrada in the Collections of the Royal Scottish Museum, Edinburgh. Edinburgh: The Museum 29 p.

Nelson DR. 1975. Ecological Distribution of Tardigrades on Roan Mountain, Tennessee-North Carolina. Memorie dell'Instituto Italiano di Idrobiologia. 32(Suppl.):225-276.

Nelson DR. 2002. Current status of the Tardigrada: evolution and ecology. Integr Comp Biol. 
42(3):652-659.

doi: 10.1093/icb/42.3.652

Nichols PB. 1999. The ecological distribution of the Tardigrada on Dugger Mountain (NE Alabama) with respect to seasonal and altitudinal variation [PhD Thesis]. Jacksonville State University. $18 \mathrm{p}$.

Nichols PB, Romano FA, Nelson DR. 2001. Seasonal and altitudinal variation in the distribution and abundance of Tardigrada on Dugger Mountain, Alabama. Zool Anz. 240(3-4):501-504. doi: 10.1078/0044-5231-00059

Okay AI. 2008. Geology of Turkey: a synopsis. Anschnitt. 21:19-42.

Pechlaner R. 1971. Factors that control the production rate and biomass of phytoplankton in high-mountain lakes. Int Ver The. 19(1):125-145. doi: 10.1080/05384680.1971.11903926

Ramazzotti G. 1956. I Tardigradi delle Alpi. Memorie dell'Instituto Italiano di Idrobiologia. 9:273-290.

Ramazzotti G. Maucci W. 1983. II Phylum Tardigrada. Memorie dell'Instituto Italiano di Idrobiologia. 41:11012.

Rodríguez-Roda J. 1951. Algunos datos sobre la distribución de los tardígrados españoles. Boletín de la Real Sociedad Española de Historia Natural. 49:7583.

Spallanzani L. 1776. Opuscoli di Fisica animale e vegetabile. Modena: Societa Tipografica 607 p.

Stec D, Morek W, Gąsiorek P, Michalczyk Ł. 2018. Unmasking hidden species diversity within the
Ramazzottius oberhaeuseri complex, with an integrative redescription of the nominal species for the family Ramazzottiidae (Tardigrada: Eutardigrada: Parachela). Systematics and Biodiversity. 16(4):357376. doi: 10.1080/14772000.2018.1424267

Tekatlı Ç, Altındağ A. 2017. New records for Tardigrada from Cyprus. North-West J Zool. 13(2):358-360.

Trygvadóttir BV, Kristensen RM. 2013. A zoogeographic study of the limnoterrestrial fauna on the Faroe islands. J Limnol. 72(1):113-122. doi: 10.4081/jlimnol.2013.s1.e14

Utsugi K. 1997. On the relation between tardigrade fauna and bryophyte flora in Toyama Prefecture. Bulletin of the Toyama Science Museum. 20:57-71.

Ürkmez D, Ostrowska M, Roszkowska M, Gawlak M, Zawierucha K, Kristensen RM, Kaczmarek Ł. 2018. Description of Megastygarctides sezginii sp. nov. (Tardigrada: Arthrotardigrada: Stygarctidae) from the Turkish Black Sea coast and a key to the genus Megastygarctides. Mar Biol Res. 14(1):1-16. doi: 10.1080/17451000.2017.1342845

Vicente F, Bertolani R. 2013. Considerations on the taxonomy of the Phylum Tardigrada. Zootaxa. 3626(2):245-248. doi: 10.11646/zootaxa.3626.2.2

Zhang P, Sun XZ. 2014. A new species of the genus Macrobiotus (Tardigrada: Macrobiotidae) from Southeastern China. Zoological Systematics. 39(2):224-228. 